DOI: $10.15193 /$ zntj/2019/120/297

\author{
ALEKSANDRA OŁDAK, DOROTA ZIELIŃSKA, \\ DANUTA KOŁOŻYN-KRAJEWSKA
}

\title{
PORÓWNANIE AKTYWNOŚCI ANTAGONISTYCZNEJ WYKAZYWANEJ PRZEZ SZCZEPY BAKTERII FERMENTACJI MLEKOWEJ WYIZOLOWANE Z RÓŻNYCH RODZAJÓW ŻYWNOŚCI TRADYCYJNEJ
}

\author{
Streszczenie
}

Celem pracy była statystyczna analiza związków pomiędzy źródłem izolacji 66 szczepów bakterii fermentacji mlekowej (LAB), ich przynależnością filogenetyczną do określonego rodzaju i gatunku a wykazywanymi właściwościami przeciwdrobnoustrojowymi w stosunku do bakterii Listeria monocytogenes, Salmonella enteritidis i Escherichia coli. Analizę przeprowadzono na podstawie danych zebranych w trakcie badań w latach 2014 - 2019, prowadzonych w Zakładzie Higieny i Zarządzania Jakością Żywności Katedry Technologii Gastronomicznej i Higieny Żywności Szkoły Głównej Gospodarstwa Wiejskiego w Warszawie. Zebrane dane obejmowały średnice stref zahamowania wzrostu drobnoustrojów wskaźnikowych obserwowane w metodzie dyfuzyjnej studzienkowej, w której jako czynnik hamujący wykorzystywano pełne hodowle LAB (WBC), bezkomórkowy płyn pohodowlany (CFS) oraz zneutralizowany, traktowany katalazą, płyn pohodowlany (CFN). Spośród analizowanych szczepów LAB najwyższą aktywność przeciwdrobnoustrojową wykazywały szczepy gatunku Lactobacillus plantarum, a najniższą Lb. fermentum. Szczepy wyizolowane z serów regionalnych (a szczególnie z oscypka) charakteryzowały się największym antagonizmem w stosunku do L. monocytogenes, zjawisko to występowało zarówno w WBC, CFS, jak i CFN. Wykazano, że badane szczepy LAB charakteryzują się zróżnicowanymi właściwościami przeciwdrobnoustrojowymi, przy czym zróżnicowanie to jest zależne od takich czynników, jak źródło izolacji oraz przynależność filogenetyczna.

Słowa kluczowe: aktywność przeciwdrobnoustrojowa, bakterie fermentacji mlekowej, Lactobacillus, żywność tradycyjna, izolowanie

\section{Wprowadzenie}

Bakterie fermentacji mlekowej (ang. Lactic Acid Bacteria, LAB) to zróżnicowana filogenetycznie grupa mikroorganizmów, których wspólną cechą jest wytwarzanie

Mgr inż. A. Otdak, dr inż. D. Zielińska, prof. dr hab. D. Kolożyn-Krajewska, Katedra Technologii Gastronomicznej i Higieny Żywności, Wydz. Nauk o Żywieniu Człowieka i Konsumpcji, Szkoła Główna Gospodarstwa Wiejskiego w Warszawie, ul. Nowoursynowska 159 C, 02-776 Warszawa.

Kontakt: aleksandra_oldak@sggw.pl 
kwasu mlekowego jako ubocznego produktu beztlenowego procesu oddychania komórkowego. Właściwości przeciwdrobnoustrojowe LAB są szczepozależne i wynikają przede wszystkim ze zdolności do obniżania wartości pH środowiska $[2,18]$ poprzez syntezę kwasów organicznych: mlekowego, octowego i propionowego, jak również syntezę nadtlenku wodoru, bakteriocyn oraz związków bakteriocynopodobnych i innych [15].

Hamowanie wzrostu mikroorganizmów niepożądanych w żywności stanowi podstawę technologicznego wykorzystania LAB w procesach zmierzających do wydłużenia trwałości produktów spożywczych [13, 16, 19].

Ze względu na długą tradycję bezpiecznego stosowania wiele rodzajów bakterii należących do LAB zostało wpisanych na listę GRAS (ang. Generally Recognized as Safe - powszechnie uznane za bezpieczne) [5]. Co więcej, w grupie tej znajdują się mikroorganizmy o udowodnionych właściwościach probiotycznych, czyli wykazujące pozytywny wpływ na zdrowie człowieka. Obecnie, gdy konsumenci poszukują żywności minimalnie przetworzonej, ale o możliwie długim terminie przydatności do spożycia, duże nadzieje wiąże się z wykorzystaniem szczepów LAB oraz ich metabolitów w procesie utrwalania żywności. Bogatym źródłem LAB jest żywność fermentowana spontanicznie, która zawiera zróżnicowaną, naturalną mikroflorę. W ostatnich latach, w Polsce i na świecie, prowadzone są liczne badania w zakresie oceny aktywności antagonistycznej LAB w stosunku do drobnoustrojów patogennych. Wciąż trwają poszukiwania kolejnych, naturalnych źródeł izolacji nowych szczepów [1, 7, 13, 16, 19].

Badania prowadzone w latach 2014 - 2019 w Zakładzie Higieny i Zarządzania Jakością Żywności Szkoły Głównej Gospodarstwa Wiejskiego w Warszawie potwierdziły, że LAB wyizolowane z różnych rodzajów fermentowanej żywności tradycyjnej wykazują wysoką aktywność antagonistyczną w stosunku do bakterii patogennych, tj. Listeria monocytogenes, Salmonella enteritidis, Escherichia coli i in. [18, 22, 23]. Zaobserwowano, że drobnoustroje z grupy LAB mogą znacznie różnić się między sobą profilem antagonizmu w stosunku do mikroorganizmów wskaźnikowych.

Celem niniejszej pracy była statystyczna analiza związków pomiędzy źródłem izolacji szczepu LAB, jego przynależnością filogenetyczną do określonego rodzaju i gatunku a wykazywanymi właściwościami przeciwdrobnoustrojowymi w stosunku do wybranych drobnoustrojów niepożądanych w żywności.

\section{Material i metody badań}

Przedmiot badań stanowiły dane zebrane w latach 2014 - 2019 w ramach analiz właściwości przeciwdrobnoustrojowych LAB, wykonanych w Zakładzie Higieny i Zarządzania Jakością Żywności SGGW, opublikowane w recenzowanych czasopismach $[18,22,23]$. Dane te obejmowały średnice stref zahamowania wzrostu drobnoustrojów wskaźnikowych (L. monocytogenes ATCC 15313, L. monocytogenes ATCC 
19111, L. monocytogenes ATCC 7644, E. coli ATCC 10536, S. enteritidis ATCC 13076) obserwowane w metodzie dyfuzyjnej studzienkowej, w której jako czynnik hamujący wykorzystywano pełne hodowle LAB (WBC), bezkomórkowy płyn pohodowlany (CFS) oraz zneutralizowany, traktowany katalazą, płyn pohodowlany (CFN). Spośród analizowanych 66 szczepów LAB 41 należało do gatunku Lb. plantarum, po 9 - do gatunków Lb. fermentum i Pediococcus pentosaceus, a 7 - do gatunku Lb. brevis. Źródłem izolacji szczepów analizowanych w badaniach były sery regionalne - oscypek (17) i ser koryciński (12), fermentowane wyroby mięsne (schab - 6, kiełbasa -8 , baleron -7 ) oraz serwatka kwasowa (16). Wszystkie oznaczenia były wykonywane w 3 powtórzeniach, co uwzględniono w analizie statystycznej.

Analizy statystyczne prowadzono z użyciem programu Statistica 13.1 (StatSoft, Polska). W celu stwierdzenia statystycznej istotności obserwowanych różnic aktywności antagonistycznej pomiędzy szczepami, gatunkami oraz rodzajami drobnoustrojów a źródłami izolacji, przeprowadzono jednoczynnikową analizę wariancji ANOVA. Do porównania wartości średnich post hoc zastosowano test HSD Tukeya. Różnicę uznawano za statystycznie istotną przy $\mathrm{p}<0,05$. Na podstawie analizy dyskryminacyjnej wytypowano zmienne, które w najwyższym stopniu determinują różnice pomiędzy przypadkami. Następnie dane poddano wielowymiarowej analizie skupień, a uzyskane zgrupowania oceniono pod względem jednorodności obserwowanego czynnika (gatunek/rodzaj drobnoustroju, źródło izolacji). Badania poszerzono o wielowymiarową analizę czynnikową oraz analizę składowych głównych, aby ocenić wagi i liczbę czynników determinujących zmienność statystyczną w badanej próbie.

\section{Wyniki i dyskusja}

W tab. 1. przedstawiono wyniki wielowymiarowego testu istotności (testu Wilksa) dla wszystkich rozpatrywanych czynników determinujących zmienność w grupie.

Tabela 1. Wartości charakteryzujące istotność różnic (test Wilksa)

Table 1. Values characterizing the significance of differences (Wilks test)

\begin{tabular}{||c|c|c|c|c|c||}
\hline $\begin{array}{c}\text { Czynnik } \\
\text { Factor }\end{array}$ & $\begin{array}{c}\text { Wartość } \\
\text { Value }\end{array}$ & $\mathrm{F}$ & $\begin{array}{c}\text { Efekt df } \\
\text { df effect }\end{array}$ & $\begin{array}{c}\text { Błąd df } \\
\text { df error }\end{array}$ & $\mathrm{p}$ \\
\hline $\begin{array}{c}\text { Źródło izolacji } \\
\text { Source of isolation }\end{array}$ & 0,002 & 23,05 & 90 & 1018,862 & 0,000000 \\
\hline Rodzaj / Genus & 0,817 & 2,755 & 15 & 185 & 0,000742 \\
\hline Gatunek / Species & 0,346 & 5,194 & 45 & 544,427 & 0,000000 \\
\hline Szczep / Strain & 0,000 & 4,655 & 990 & 1832,957 & 0,000000 \\
\hline
\end{tabular}

Rozpatrywane $\mathrm{w}$ analizie czynniki determinowały występowanie różnic statystycznie istotnych pomiędzy obserwowanymi mikroorganizmami. Zmienność w grupie 
była w największym stopniu determinowana przez źródło izolacji szczepu. Na rys. 1., 2. i 3. przedstawiono średnice stref zahamowania wzrostu drobnoustrojów wskaźnikowych, obserwowane dla szczepów w zależności od ich przynależności filogenetycznej i źródła izolacji. Spośród analizowanych szczepów LAB najwyższą aktywność przeciwdrobnoustrojową wykazywały $L b$. plantarum, a najniższą $-L b$. fermentum (rys. 1).

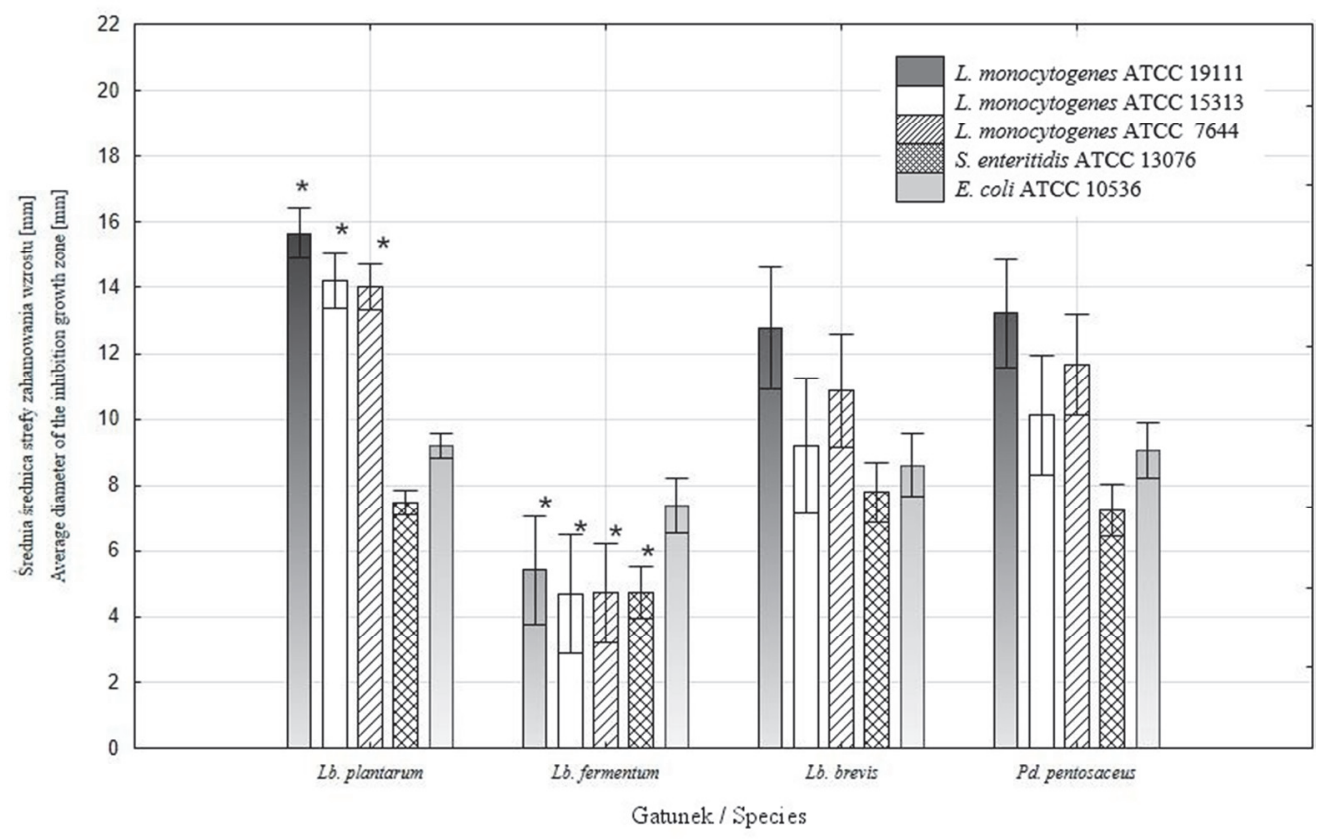

Objaśnienia / Explanatory notes:

$\mathrm{Na}$ rysunku przedstawiono wartości średnie (w postaci słupków) i odchylenia standardowe (w postaci odcinków) / Figure shows mean values (bars) and standard deviations (line segments); Znakiem , ," oznaczono różnice statystycznie istotne $(\mathrm{p}<0,01)$ pomiędzy gatunkami / Sign , ${ }^{*}$ " indicates statistically significant differences among species $(\mathrm{p}<0.01)$.

Rys. 1. Średnice stref zahamowania wzrostu drobnoustrojów wskaźnikowych [mm] obserwowane dla pełnych hodowli LAB (WBC) w obecności badanych bakterii

Fig. 1. Diameters of the growth inhibition zones of indicator microorganisms [mm], as tracked for whole $\mathrm{LAB}(\mathrm{WBC})$ cultures in the presence of tested bacteria

Nie obserwowano różnic statystycznie istotnych pomiędzy $L b$. brevis i $P d$. pentosaceus. Szczególnie interesująca wydaje się bardzo wysoka aktywność antagonistyczna w stosunku do L. monocytogenes, charakteryzująca analizowane szczepy Lb. plantarum. Gatunek ten jest jednym z bardziej rozpowszechnionych w środowisku żywności fermentowanej i tradycyjnej. Potencjał przeciwdrobnoustrojowy Lb. plantarum wynika z obecności różnych regionów DNA kodujących wytwarzanie bakteriocyn (np. planta- 
rycyny), jak również egzopolisacharydów i genów zaangażowanych w metabolizm cukru. Wskazane właściwości sprawiają, że gatunek ten wykazuje duże zdolności adaptacyjne i probiotyczne [8].

Arena i wsp. [4] również obserwowali zdolność istotnego hamowania wzrostu L. monocytogenes, a także $E$. coli i $S$. aureus, wykazywaną przez Lb. plantarum. Wielu badaczy donosi również o skuteczności antagonistycznej LAB w stosunku do Listeria spp., co może być przydatne technologicznie w utrwalaniu żywności gotowej do spożycia czy minimalnie przetworzonej.

Pomiędzy analizowanymi zgrupowaniami (rodzaje i gatunki badanych bakterii) nie odnotowano różnic w zakresie antagonizmu w stosunku do E. coli. Oddziaływanie to można ocenić jako średnie (średnica stref zahamowania wzrostu w zakresie $6,5 \div$ $10,0 \mathrm{~mm}$ ). Aktywność przeciwko $S$. enteritidis również można określić jako średnią (średnice $4,0 \div 8,5 \mathrm{~mm}$ ), przy czym była ona istotnie niższa w przypadku $L b$. fermentum $\mathrm{w}$ porównaniu $\mathrm{z}$ pozostałymi badanymi rodzajami i gatunkami bakterii. Wielu badaczy donosi o aktywności przeciwdrobnoustrojowej tych gatunków LAB [3, 9, 12, 25].

Po przeanalizowaniu właściwości przeciwdrobnoustrojowych szczepów w zależności od źródła izolacji (rys. 2) wykazano, że szczepy wyizolowane z serów regionalnych (szczególnie z oscypka) charakteryzowały się bardzo wysokim antagonizmem w stosunku do wszystkich badanych szczepów L. monocytogenes, szczególnie w przypadku pełnych hodowli LAB. Sip i wsp. [24] stwierdzili, że szczepy wyizolowane z innego sera podhalańskiego - gołki również charakteryzowały się bardzo wysoką aktywnością antagonistyczną w stosunku do Listeria sp., a niektóre z nich były zdolne do syntezy bakteriocyn [24]. Szczepy wyizolowane z sera korycińskiego hamowały istotnie najsilniej wzrost $E$. coli. Najniższą aktywność przeciwdrobnoustrojową zaobserwowano w przypadku szczepów wyizolowanych z serwatki kwasowej. Interesujące, że w przypadku tych szczepów ich aktywność antagonistyczna w stosunku do L. monocytogenes była niższa niż antagonizm w stosunku do E. coli.

Na rys. 3. przedstawiono aktywność przeciwdrobnoustrojową bezkomórkowego płynu pohodowlanego badanych szczepów LAB. Medium to charakteryzowało się słabszymi właściwościami przeciwdrobnoustrojowymi, w porównaniu z pełnymi hodowlami, ze względu na pozbawienie go żywych komórek bakterii, które mogą wykazywać działanie przeciwdrobnoustrojowe na drodze innych mechanizmów.

Szczególnie zauważalna była niższa aktywność antagonistyczna bezkomórkowego płynu pohodowlanego (CFS) w stosunku do L. monocytogenes (zmniejszenie stref zahamowania wzrostu nawet o $4 \div 5 \mathrm{~mm}$ w porównaniu z pełną hodowlą). Zjawisko to może być związane $\mathrm{z}$ wyższą zdolnością adaptacyjną $L$. monocytogenes $\mathrm{w}$ porównaniu z pozostałymi drobnoustrojami wskaźnikowymi. Ramos i wsp. [20] wykazali po zastosowaniu GC-MS, że supernatant z hodowli Lb. plantarum jest wieloskładnikową mie- 
szaniną biologicznie aktywną, zawierającą m.in. takie substancje przeciwdrobnoustrojowe, jak kwasy: octowy, bursztynowy, benzoesowy i masłowy, oraz etanol i 5-metylohydantoina [20].

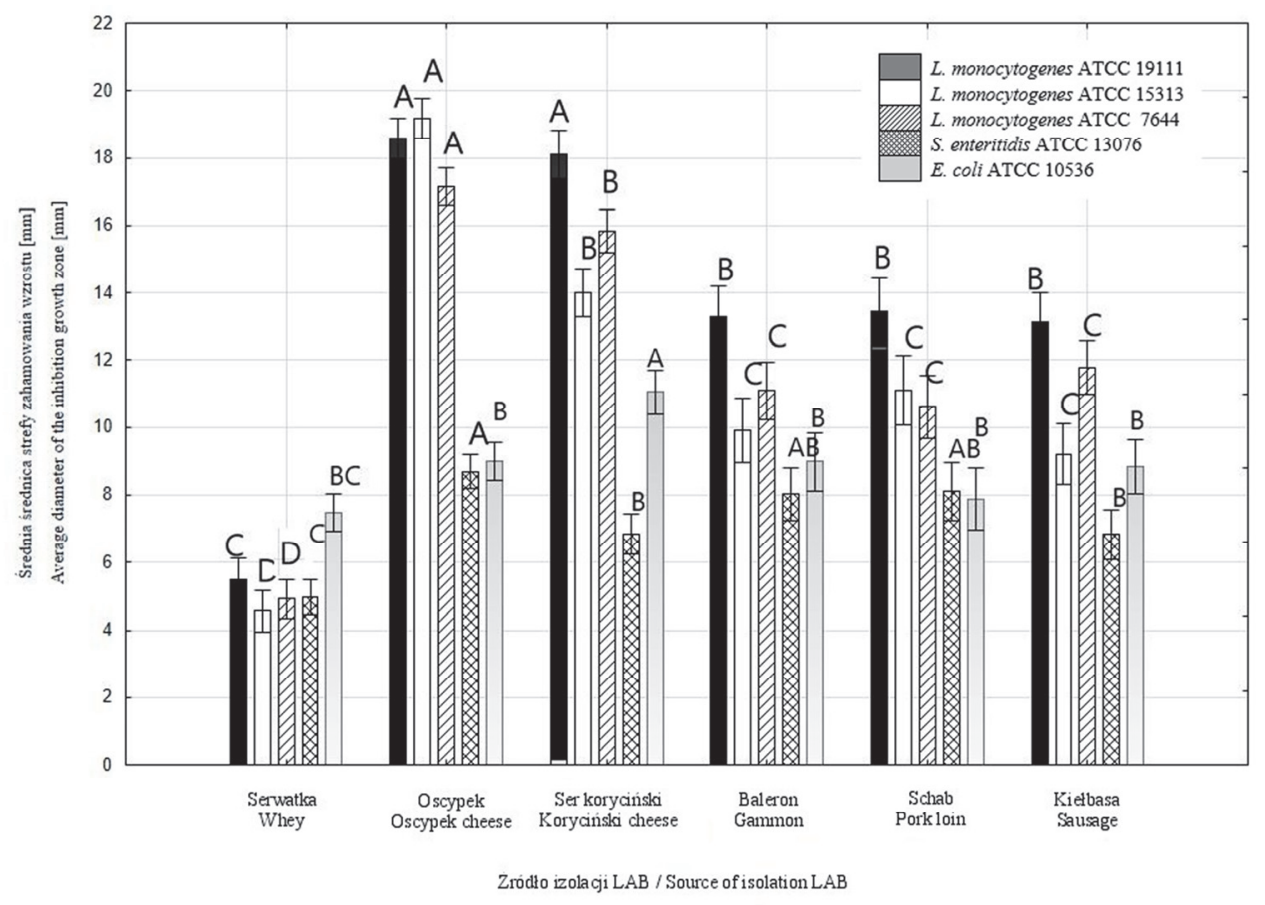

Objaśnienie / Explanatory notes:

A, B, C, D - wartości średnie oznaczone różnymi literami różną się statystycznie istotnie $(\mathrm{p}<0,01)$ ze względu na źródła izolacji szczepów / mean values denoted by different letters differ statistically significantly due to strain isolation sources $(\mathrm{p}<0.01)$.

Rys. 2. Średnice stref zahamowania wzrostu drobnoustrojów wskaźnikowych [mm] w zależności od stosowanego źródła izolacji LAB, obserwowane dla pełnych hodowli (WBC) LAB w obecności badanych bakterii

Fig. 2. Diameters of growth inhibition zones of indicator microorganisms [mm] that depend on source of LAB isolation as tracked for whole $\mathrm{LAB}$ (WBC) cultures in the presence of tested bacteria

Zastosowanie CFS może być interesującą strategią przedłużania trwałości żywności. Wybrane CFS zawierające substancje chemiczne wytwarzane przez bakterie mogą być skuteczne w hamowaniu patogenów, zwłaszcza tam, gdzie nie ma możliwości dodania żywych drobnoustrojów lub też ich dodatek byłby nieskuteczny, np. w żywności poddanej chłodzeniu, w której L. monocytogenes mogłaby się namnażać, a pałeczki kwasu mlekowego - nie [4, 11, 21]. 


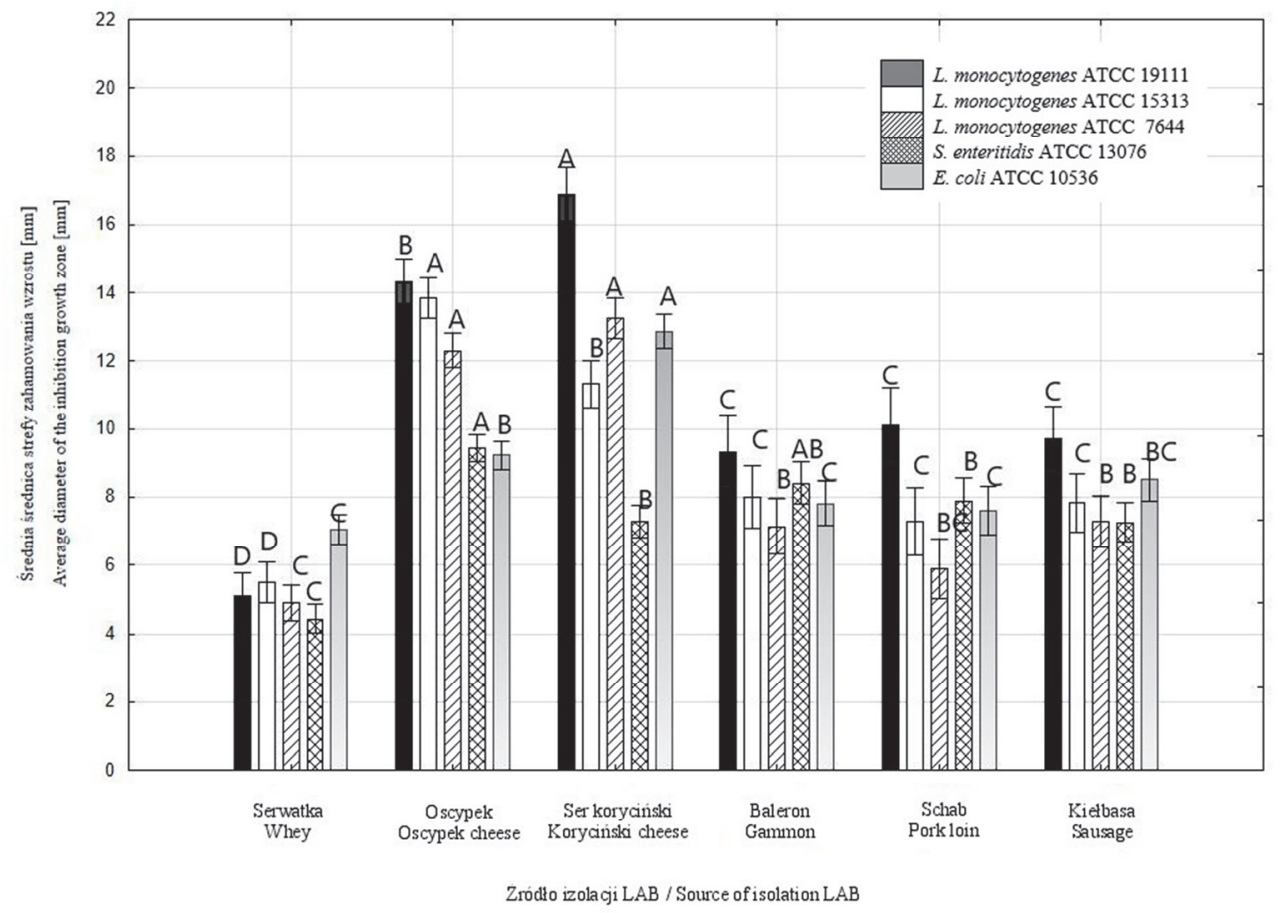

Objaśnienia jak pod rys. 2 / Explanatory notes as in Fig. 2.

Rys. 3. Średnice stref zahamowania wzrostu drobnoustrojów wskaźnikowych [mm], obserwowane w przypadku bezkomórkowego płynu pohodowlanego w obecności badanych bakterii

Fig 3. Diameters of the growth inhibition zones of indicator microorganisms [mm] as tracked for cellfree supernatant in the presence of tested bacteria

W tab. 2. przedstawiono liczbę szczepów w zneutralizowanym i traktowanym katalazą płynie pohodowlanym (CFN), pozbawionym żywych komórek bakterii, który wykazywał aktywność antagonistyczną w stosunku do drobnoustrojów wskaźnikowych.

Szczepy, których CFN wykazuje zdolność hamowania wzrostu patogenów, mogą syntetyzować substancje przeciwdrobnoustrojowe aktywne w środowisku o pH neutralnym takie, jak np. bakteriocyny [4]. Zaobserwowano, że w zależności od źródła izolacji zmienny jest udział takich szczepów w całej grupie. Należy dodać, że aktywność antagonistyczna CFN korelowała dodatnio z aktywnością antagonistyczną pełnej hodowli, co potwierdza, że syntetyzowane przez badane szczepy substancje przeciwdrobnoustrojowe zwiększają ich zdolność do konkurencji. 
Tabela 2. Liczba szczepów wykazujących aktywność antagonistyczną w zneutralizowanym płynie pohodowlanym - CFN (średnica strefy zahamowania wzrostu $0,5 \div 3,5 \mathrm{~mm}$ )

Table 2. The number of strains showing antagonistic activity in CFN (diameter of growth inhibition zone $0.5 \div 3.5 \mathrm{~mm}$ )

\begin{tabular}{|c|c|c|c|c|c|c|}
\hline \multirow{3}{*}{$\begin{array}{l}\text { Szczep wskaźni- } \\
\text { kowy } \\
\text { Indicator strain }\end{array}$} & \multicolumn{6}{|c|}{ Źródło izolacji / Source of isolation } \\
\hline & \multirow{2}{*}{$\begin{array}{c}\text { Serwatka } \\
\text { kwasowa } \\
\text { Acid } \\
\text { whey }\end{array}$} & \multicolumn{2}{|c|}{$\begin{array}{l}\text { ser regionalny } \\
\text { regional cheese }\end{array}$} & \multicolumn{3}{|c|}{$\begin{array}{c}\text { fermentowany produkt mięsny } \\
\text { fermented meat product }\end{array}$} \\
\hline & & oscypek & koryciński & $\begin{array}{l}\text { baleron } \\
\text { gammon }\end{array}$ & $\begin{array}{c}\text { schab } \\
\text { pork loin }\end{array}$ & $\begin{array}{l}\text { kiełbasa } \\
\text { sausage }\end{array}$ \\
\hline $\begin{array}{l}\text { L. monocytogenes } \\
\text { ATCC } 19111\end{array}$ & $\begin{array}{c}2 \mathrm{z} 16 \\
2 \text { from } 16\end{array}$ & $\begin{array}{c}17 \text { z } 17 \\
17 \text { from } 17\end{array}$ & $\begin{array}{c}0 \mathrm{z} 12 \\
0 \text { from } 12\end{array}$ & $\begin{array}{c}1 \mathrm{z} 7 \\
1 \text { from } 7\end{array}$ & $\begin{array}{c}2 \mathrm{z} 6 \\
2 \text { from } 6\end{array}$ & $\begin{array}{c}0 \mathrm{z} 8 \\
0 \text { from } 8\end{array}$ \\
\hline $\begin{array}{l}\text { L. monocytogenes } \\
\text { ATCC } 15313\end{array}$ & $\begin{array}{c}2 \mathrm{z} 16 \\
2 \text { from } 16\end{array}$ & $\begin{array}{c}17 \mathrm{z} 17 \\
17 \text { from } 17\end{array}$ & $\begin{array}{c}0 \mathrm{z} 12 \\
0 \text { from } 12\end{array}$ & $\begin{array}{c}1 \mathrm{z} 7 \\
1 \text { from } 7\end{array}$ & $\begin{array}{c}2 \mathrm{z} 6 \\
2 \text { from } 6\end{array}$ & $\begin{array}{c}0 \mathrm{z} 8 \\
0 \text { from } 8\end{array}$ \\
\hline $\begin{array}{l}\text { L. monocytogenes } \\
\text { ATCC } 7644\end{array}$ & $\begin{array}{c}2 \mathrm{z} 16 \\
2 \text { from } 16\end{array}$ & $\begin{array}{c}17 \mathrm{z} 17 \\
17 \text { from } 17\end{array}$ & $\begin{array}{c}0 \mathrm{z} 12 \\
0 \text { from } 12\end{array}$ & $\begin{array}{c}1 \mathrm{z} 7 \\
1 \text { from } 7\end{array}$ & $\begin{array}{c}2 \mathrm{z} 6 \\
2 \text { from } 6\end{array}$ & $\begin{array}{c}0 \mathrm{z} 8 \\
0 \text { from } 8\end{array}$ \\
\hline $\begin{array}{l}\text { S. enteritidis } \\
\text { ATCC } 13076\end{array}$ & $\begin{array}{c}2 \mathrm{z} 16 \\
2 \text { from } 16\end{array}$ & $\begin{array}{c}17 \text { z } 17 \\
17 \text { from } 17 \\
\end{array}$ & $\begin{array}{c}0 \mathrm{z} 12 \\
0 \text { from } 12\end{array}$ & $\begin{array}{c}1 \mathrm{z} 7 \\
1 \text { from } 7\end{array}$ & $\begin{array}{c}0 \mathrm{z} 6 \\
0 \text { from } 6\end{array}$ & $\begin{array}{c}1 \mathrm{z} 8 \\
1 \text { from } 8\end{array}$ \\
\hline $\begin{array}{c}\text { E.coli ATCC } \\
10536\end{array}$ & $\begin{array}{c}2 \mathrm{z} 16 \\
2 \text { from } 16\end{array}$ & $\begin{array}{c}17 \text { z } 17 \\
17 \text { from } 17\end{array}$ & $\begin{array}{c}8 \mathrm{z} 12 \\
8 \text { from } 12\end{array}$ & $\begin{array}{c}2 \mathrm{z} 7 \\
2 \text { from } 7\end{array}$ & $\begin{array}{c}0 \mathrm{z} 6 \\
0 \text { from } 6\end{array}$ & $\begin{array}{c}1 \mathrm{z} 8 \\
1 \text { from } 8\end{array}$ \\
\hline
\end{tabular}

Wyniki cząstkowe analizy dyskryminacyjnej danych w zależności od źródła izolacji przedstawiono $w$ tab. 3. Stwierdzono, że niemal wszystkie zmienne determinują zmienność w grupie, co podkreśla znaczenie źródła izolacji LAB dla ich aktywności antagonistycznej.

Zastosowanie analizy dyskryminacyjnej umożliwiło także wykazanie, że największy wpływ na zmienność w grupie ma:

- w zależności od rodzaju LAB - aktywność antagonistyczna wyrażana w stosunku do L. monocytogenes ATCC 7644 przez CFS $(\mathrm{p}=0,0089)$, S. enteritidis ATCC 13076 przez CFS $(\mathrm{p}=0,045)$ i CFN $(\mathrm{p}=0,018)$, oraz E. coli ATCC 10536 przez CFS $(p=0,011)$

- w zależności od gatunku LAB - aktywność antagonistyczna wyrażana w stosunku do L. monocytogenes ATCC 19111 przez WBC $(\mathrm{p}=0,023)$, L. monocytogenes ATCC 15313 przez WBC $(\mathrm{p}=0,0015)$, L. monocytogenes ATCC 7644 przez WBC $(\mathrm{p}=0,026)$, S. enteritidis ATCC 13076 przez CFS $(\mathrm{p}=0,0001)$ i CFN $(\mathrm{p}=0,025)$.

Na podstawie analizy składowych głównych wykazano, że zmienność w grupie w zależności od źródła izolacji determinowana jest przez 15 czynników, przy czym 3 pierwsze określają ją w 84,54\%. Na rys. 4. przedstawiono projekcję przypadków na płaszczyznę 2 czynników. Zaobserwowano utworzenie 4 wyraźnych skupień, grupujących rezultaty otrzymane dla szczepów wyizolowanych z określonych źródeł. 
Tabela 3. Podsumowanie analizy funkcji dyskryminacyjnej w zależności od źródła izolacji szczepu LAB (15 zmiennych, 6 grup)

Table 3. Summary of discriminant function analysis depending on source of isolation of LAB strain (15 variables, 6 groups)

\begin{tabular}{|c|c|c|c|c||}
\hline Zmienna / Variable & $\begin{array}{c}\text { Lambda } \\
\text { Wilksa } \\
\text { Wilks' } \\
\text { lambda }\end{array}$ & $\begin{array}{c}\text { Cząstk. Wilksa } \\
\text { Partial. Wilks' }\end{array}$ & $\mathrm{p}$ & $\begin{array}{c}\text { Tolerancja } \\
\text { Tolerance }\end{array}$ \\
\hline L. monocytogenes ATCC 19111 (WBC) & 0,003664 & 0,836595 & 0,000006 & 0,682182 \\
\hline L. monocytogenes ATCC 19111 (CFS) & 0,003640 & 0,842182 & 0,000010 & 0,583704 \\
\hline L. monocytogenes ATCC 19111 (CFN) & 0,003471 & 0,883035 & 0,000454 & 0,529577 \\
\hline L. monocytogenes ATCC 15313 (WBC) & 0,004265 & 0,718699 & 0,000000 & 0,718098 \\
\hline L. monocytogenes ATCC 15313 (CFS) & 0,003183 & 0,963029 & 0,238977 & 0,703903 \\
\hline L. monocytogenes ATCC 15313 (CFN) & 0,003195 & 0,959499 & 0,191181 & 0,552675 \\
\hline L. monocytogenes ATCC 7644 (WBC) & 0,003466 & 0,884372 & 0,000511 & 0,687656 \\
\hline L. monocytogenes ATCC 7644 (CFS) & 0,003519 & 0,871184 & 0,000156 & 0,717403 \\
\hline L. monocytogenes ATCC 7644 (CFN) & 0,003391 & 0,903851 & 0,002771 & 0,498992 \\
\hline S. enteritidis ATCC 13076 (WBC) & 0,003281 & 0,934176 & 0,031878 & 0,656707 \\
\hline S. enteritidis ATCC 13076(CFS) & 0,003854 & 0,795301 & 0,000000 & 0,873316 \\
\hline S. enteritidis ATCC 13076 (CFN) & 0,003346 & 0,916187 & 0,007719 & 0,791654 \\
\hline E. coli ATCC 10536 (WBC) & 0,003488 & 0,878869 & 0,000313 & 0,787461 \\
\hline E. coli ATCC 10536 (CFS) & 0,004234 & 0,723901 & 0,000000 & 0,846930 \\
\hline E. coli ATCC 10536 (CFN) & 0,003259 & 0,940461 & 0,051028 & 0,820480 \\
\hline
\end{tabular}

Aktywność antagonistyczna wykazywana przez bakterie fermentacji mlekowej zależy od ich zdolności do produkcji takich substancji, jak: kwasy organiczne, nadtlenek wodoru, bakteriocyny, egzopolisacharydy i in. Zależność właściwości przeciwdrobnoustrojowych mikroorganizmów od źródła izolacji jest stosunkowo rzadko przedstawiana w literaturze. Astha i wsp. [17] obserwowali różnice aktywności antagonistycznej szczepów wyizolowanych z różnych źródeł. Synteza pewnych substancji przeciwdrobnoustrojowych (np. bakteriocyn) nie jest prowadzona w sposób ciągły, a może być indukowana przez określone warunki środowiska, w tym przez obecność w środowisku drobnoustroju konkurującego $[6,10,14]$. W związku z tym można przypuszczać, że szczepy wykazujące zdolność syntezy takich substancji mogły mieć kontakt $\mathrm{z}$ danym drobnoustrojem wskaźnikowym (lub innym, podatnym na działanie danej substancji przeciwdrobnoustrojowej) w środowisku stanowiącym źródło izolacji LAB. Aktywność przeciwdrobnoustrojowa szczepów LAB może być także zależna od składu źródła izolacji (zawartość makro- i mikroelementów w produkcie) oraz jego pochodzenia geograficznego. Różne obszary geograficzne charakteryzują się bowiem występowaniem typowej dla siebie puli mikroorganizmów, których cechy funkcjonalne mogą 


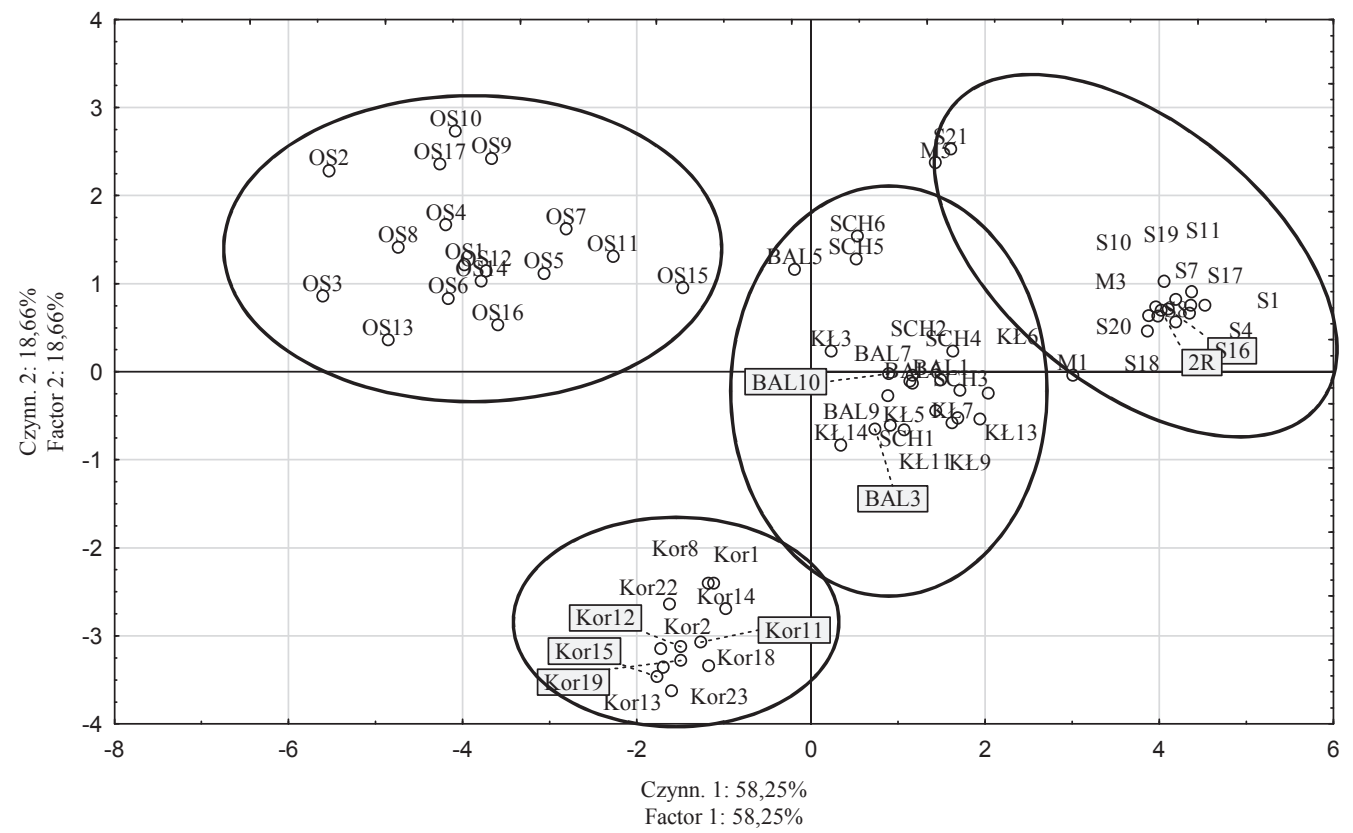

Objaśnienia / Explanatory notes:

Symbole szczepów przedstawione na rysunku wskazują na źródło izolacji szczepu: / Symbols of strains indicate source of isolation: OS - oscypek / oscypek cheese, Kor - ser koryciński / Koryciński cheese, $\mathrm{BAL}$ - baleron / gammon, $\mathrm{K} \downarrow$ - kiełbasa / sausage, $\mathrm{SCH}$ - schab / pork loin, $\mathrm{S}$ - serwatka kwasowa / acid whey.

Rys. 4. Projekcja przypadków na płaszczyznę 2 czynników wyjaśniających zmienność w grupie

Fig. 4. Projection of cases on plane of 2 factors to explain variability within group

być warunkowane czynnikami środowiskowymi i technologicznymi. Dalsza analiza produktów fermentowanych, stanowiących bogaty rezerwuar szczepów należących do LAB, może prowadzić do wytypowania źródeł szczególnie obiecujących pod względem otrzymania izolatów o określonych, korzystnych cechach funkcjonalnych, w tym o właściwościach przeciwdrobnoustrojowych.

\section{Wnioski}

1. Spośród analizowanych szczepów LAB najwyższą aktywność przeciwdrobnoustrojową wykazywały bakterie gatunku $L b$. plantarum, a najniższą - Lb. fermentum.

2. Szczepy wyizolowane z serów regionalnych (szczególnie z oscypka) charakteryzowały się największym antagonizmem w stosunku do L. monocytogenes, a zjawisko to występowało zarówno w WBC, CFS, jak i CFN. Wskazuje to na zdolność badanych szczepów do syntezy substancji o aktywności przeciwdrobnoustrojowej. 
Konieczne są dalsze badania w zakresie oceny i identyfikacji związków chemicznych determinujących właściwości antagonistyczne szczepów, szczególnie w zakresie związków aktywnych w środowisku o pH neutralnym.

3. Na podstawie analizy statystycznej wykazano, że badane szczepy LAB charakteryzują się zróżnicowanymi właściwościami przeciwdrobnoustrojowymi, przy czym zróżnicowanie to jest zależne od takich czynników, jak źródło izolacji oraz przynależność filogenetyczna.

\section{Literatura}

[1] Ahmed A.A.: In vitro screening of Lactobacillus species from homemade yoghurt for antagonistic effects against common bacterial pathogens. Jordan J. Biol. Sci. 2013, 6 (3), 211-216.

[2] Ajao O., Banwo K., Ogunremi O., Sanni A.: Antimicrobial properties and probiotic potentials of lactic acid bacteria isolated from raw beef in Ibadan, Nigeria. J. Microbiol. Biotechnol. Food Sci. 2018, 8 (2), 770-773.

[3] Archer A.C., Prakash M.H.: Probiotic attributes of Lactobacillus fermentum isolated from human feces and dairy products. Appl. Microbiol. Biotechnol., 2015, 99 (19), 8113-8123.

[4] Arena M.P., Silvain A., Normanno G., Grieco F., Drider D., Spano G., Fiocco D.: Use of Lactobacillus plantarum strains as a bio-control strategy against food-borne pathogenic microorganisms. Front. Microbiol., 2016, 7, \#464. DOI: 10.3389/fmicb.2016.00464.

[5] Bourdichon F., Casaregola S., Farrokh C., Frisvad J.C., Gerds M.L., Hammes W.P., Harnett J., Huys G., Laulund S., Ouwehand A., Powell I.B., Prajapati J.B., Seto Y., Ter Schure E., Van Boven A., Vankerckhoven V., Zgoda A., Tuijtelaars S., Hansen E.B.: Food fermentations: Microorganisms with technological beneficial use. Int. J. Food Microbiol., 2012, 154 (3), 87-97.

[6] Chanos P., Mygind T.: Co-culture-inducible bacteriocin production in lactic acid bacteria. Appl. Microbiol. Biotechnol., 2016, 100 (10), 4297-4308.

[7] Da Costa W.K.A., de Souza G.T., Brandão L.R., de Lima R.C., Garcia E.F., dos Santos Lima M., de Souza E.L., Saarela M., Magnani M.: Exploiting antagonistic activity of fruit-derived Lactobacillus to control pathogenic bacteria in fresh cheese and chicken meat. Food Res. Int., 2018, 108, 172-182.

[8] Da Silva S.S., Vitolo M., González J.M.D., de Souza Oliveira R.P.: Overview of Lactobacillus plantarum as a promising bacteriocin producer among lactic acid bacteria. Food Res. Int., 2014, 64, 527-536.

[9] Davoodabadi A., Soltan Dallal M.M., Rahimi Foroushani A., Douraghi M., Sharifi Yazdi M.K., Amin Harati F.: Antibacterial activity of Lactobacillus spp. isolated from the feces of healthy infants against enteropathogenic bacteria. Anaerobe, 2015, 34, 53-58.

[10] Gutiérrez-Cortés C., Suarez H., Buitrago G., Nero L.A., Todorov S.D.: Enhanced bacteriocin production by Pediococcus pentosaceus 147 in co-culture with Lactobacillus plantarum LE27 on cheese whey broth. Front. Microbiol., 2018, 9, \#2952. DOI: 10.3389/fmicb.2018.02952.

[11] Hartmann H.A., Wilke T., Erdmann R.: Efficacy of bacteriocin-containing cell-free culture supernatants from lactic acid bacteria to control Listeria monocytogenes in food. Int. J. Food Microbiol., 2011, 146 (2), 192-199.

[12] Klayraung S., Okonogi S.: Antibacterial and antioxidant activities of acid and bile resistant strains of Lactobacillus fermentum isolated from Miang. Brazilian J. Microbiol., 2009, 40 (4), 757-766.

[13] Leite A.M.O., Miguel M.A.L., Peixoto R.S.: Probiotic potential of selected lactic acid bacteria strains isolated from Brazilian kefir grains. J. Dairy Sci., 2015, 98 (6), 3622-3632. 
[14] Maldonado-Barragán A., Caballero-Guerrero B., Lucena-Padrós H., Ruiz-Barba J.L.: Induction of bacteriocin production by coculture is widespread among plantaricin-producing Lactobacillus plantarum strains with different regulatory operons. Food Microbiol., 2013, 33 (1), 40-47.

[15] Moračanin-Vesković S.M.V., Dukić D.A., Memiši N.R.: Bacteriocins produced by lactic acid bacteria - a review. Acta Periodica Technol., 2014, 45, 271-283.

[16] Muruzović M.Ž., Mladenović K.G., Žugić P.T.D., Čomić L.R.: Characterization of lactic acid bacteria isolated from traditionally made Serbian Cheese and evaluation of their antagonistic potential against Enterobacteriaceae. J. Food Process. Preserv. 2018, 42 (4), \#13577. DOI: 10.1111/jfpp.13577.

[17] Astha N., Avnish K., Madhusudan H.V., Bhola N.: In-vitro screening of antibacterial activity of lactic acid bacteria against common enteric pathogens. J. Biom. Sci., 2012, 1(4), \#2. DOI: $10.3823 / 1010$.

[18] Ołdak A., Zielińska D., Rzepkowska A., Kołożyn-Krajewska D.: Comparison of antibacterial activity of Lactobacillus plantarum strains isolated from two different kinds of regional cheeses from Poland: Oscypek and Korycinski cheese. BioMed Res. Int., 2017, \#6820369, 1-10. DOI: 10.1155/2017/6820369.

[19] Perin L.M., Nero L.A.: Antagonistic lactic acid bacteria isolated from goat milk and identification of a novel nisin variant Lactococcus lactis. BMC Microbiol., 2014, 14 (1), 1-21.

[20] Ramos A.N., Sesto Cabral M.E., Arena M.E., Arrighi C.F., Arroyo Aguilar A.A., Valdéz J.C.: Compounds from Lactobacillus plantarum culture supernatants with potential pro-healing and antipathogenic properties in skin chronic wounds. Pharmac. Biology, 2015, 53 (3), 350-358.

[21] Rodríguez-Pazo N., Vázquez-Araújo L., Pérez-Rodríguez N., Cortés-Diéguez S., Domínguez J.M.: Cell-free supernatants obtained from fermentation of cheese whey hydrolyzates and phenylpyruvic acid by Lactobacillus plantarum as a source of antimicrobial compounds, bacteriocins, and natural aromas. Appl. Bioch. Biotechnol., 2013, 171 (4), 1042-1060.

[22] Rzepkowska A., Zielińska D., Ołdak A., Kołożyn Krajewska D.: Organic whey as a source of Lactobacillus strains with selected technological and antimicrobial properties. Int. J. Food Sci. Technol., 2017, 52 (9), 1983-1994.

[23] Rzepkowska A., Zielińska D., Ołdak A., Kołożyn-Krajewska D.: Safety assessment and antimicrobial properties of the lactic acid bacteria strains isolated from polish raw fermented meat products. Int. J. Food Properties, 2017, 20 (11), 2736-2747.

[24] Sip A., Więckowicz M., Olejnik-Schmidt A., Grajek W.: Anti-Listeria activity of lactic acid bacteria isolated from golka, a regional cheese produced in Poland. Food Control, 2012, 26, 117-124.

[25] Tahlaïti H., Dalache F., Homrani A., Nemmiche S.: Characterization and screening for probiotic potential of Lactic Acid Bacteria isolated from traditionally fermented wheat "Hamoum." South Asian J. Experiment. Biol., 2017, 7 (4), 181-190.

\section{COMPARISON OF ANTAGONISTIC ACTIVITY OF LACTIC ACID BACTERIA ISOLATED FROM VARIOUS TYPES OF TRADITIONAL FOOD}

$$
\text { S u m m a r y }
$$

The objective of the research study was a statistical analysis of the correlations between the source of isolation of 66 lactic bacteria (LAB) strains, their phylogenetic affiliation to a specific genus and species, and the verified antimicrobial properties against Listeria monocytogenes, Salmonella enteritidis and Escherichia coli. The analysis was performed based on the data collected during a study project conducted in the Department of Hygiene and Food Quality Management at the 'SGGW' Warsaw University of Life 
Sciences in 2014 - 2019. The collected data included the diameters of inhibition zones of the indicator microorganisms as tracked in a well diffusion method, in which the following was used as inhibitory factors: full LAB cultures (WBC), a cell-free supernatant (CFS) and a neutralized, catalase treated cellfree supernatant (CFN). Of the LAB strains analysed, the highest antimicrobial activity was found in the $L b$. plantarum strains, and the lowest in the Lb. fermentum strains. The strains isolated from the regional cheeses (particularly from 'oscypek') were characterised by the greatest antagonism towards L. monocytogenes; that phenomenon occurred in $\mathrm{WBC}, \mathrm{CFS}$ as well as in CFN. It was shown that the LAB strains tested were characterized by diverse antimicrobial properties whereby this diversity depended on the factors such as the source of isolation and phylogenetic affiliation.

Key words: antagonistic activity, lactic acid bacteria, Lactobacillus, traditional food, isolation 